Proc. Indian Acad. Sci. (Chem. Sci.), Vol. 107, No. 2, April 1995, pp. 123-126.

(C) Printed in India.

\title{
Synthesis and antibacterial activity of rare earth perchlorate complexes of $4-(2$-hydroxynaphthylazo)antipyrine
}

\author{
$M_{\text {ALAUDEEN }}{ }^{1}$, ANNIE ABRAHAM ${ }^{1}$ and \\ P K RADHAKRISHNAN*2 \\ ${ }^{1}$ Department of Chemistry, University College, Thiruvananthapuram 695034 , India \\ ${ }^{2}$ School of Chemical Sciences, Mahatma Gandhi University, Priyadarsini Hills \\ P O, Kottayam 686560 , India
}

MS received 8 July 1994; revised 6 February 1995

\begin{abstract}
Rare earth perchlorate complexes of $4-\left(2^{\prime}\right.$-hydroxynaphthylazo) antipyrine (H-NAP) of the composition $\left[\mathrm{Ln}(\mathrm{NAP})_{2}\right] \mathrm{ClO}_{4}$ (where $\mathrm{Ln}=\mathrm{La}, \mathrm{Pr}, \mathrm{Nd}, \mathrm{Sm}$, Gd, Dy and Y) have been prepared and characterised. In these complexes NAP ${ }^{-}$ acts as a tridentate ligand and $\mathrm{ClO}_{4}^{-}$is uncoordinated. These complexes were screened for their anti-staphylococcal activity by turbidimetric assay method and were found to be more antibacterial than the ligand.
\end{abstract}

Keywords. Rare earths, complexes; antibacterial activity; $4-\left(2^{\prime}\right.$-hydroxynaphthylazo) antipyrine.

\section{Introduction}

Metal complexes of biologically active organic compounds and their derivatives are of great importance owing to their effectiveness as antibacterial drugs. However, there have not been many studies on the antibacterial activity of the complexes of rare earths. As a continuation of our earlier investigation on rare earth complexes (Alaudeen and Radhakrishnan 1990), we report here the synthesis and antibacterial studies of a few rare earth complexes of the ligand 4-(2'-hydroxynaphthylazo)antipyrine.

\section{Experimental}

\subsection{Reagents}

The perchlorates of La, Pr, Nd, Sm, Gd, Dy and Y were prepared by dissolving the respective oxides in $50 \%$ perchloric acid and crystallising the salts by evaporating the solution on a steam bath. The ligand was prepared as reported earlier (Alaudeen and Radhakrishnan 1990).

\subsection{Preparation of the complexes}

Four mmol of H-NAP in ethylacetate was refluxed for $30 \mathrm{~min}$. To this suspension $2 \mathrm{mmol}$ of a hot solution of the rare earth perchlorate in acetonitrile was added to get a clear brown solution. It was refluxed for $1 \mathrm{~h}$. The precipitated complex was filtered,

\footnotetext{
*For correspondence
} 
washed with hot acetonitrile-ethyl acetate mixture and dried in vacuum over phosphorus (V) oxide (yield: $65 \%$ ).

\subsection{Physical methods and analysis}

The complexes were analysed for metal (Nair et al 1981) and perchlorate (Kurz et al 1958) contents by conventional methods. The physical methods used in the present investigation were the same as reported earlier (Alaudeen and Radhakrishnan 1990).

The antibacterial activity of the test compounds was assayed as follows. The bacteria, Staphylococcus aureus (strain-H), obtained from National Chemical Laboratory, Pune was transferred to sterilised enrichment medium (Schmidt and Mayer 1944) and incubated for $34 \mathrm{~h}$ at $35^{\circ} \mathrm{C}$. This culture medium $(0.5 \mathrm{ml})$ was then applied to each sample of basal medium made from difcobactonutrient broth (Schmidt and Mayer 1944; Sharpe 1955), yeast extract, glucose and the test compound, in varying concentrations $(\mathrm{mg} / \mathrm{ml})$. It was then incubated for $4 \mathrm{~h}$ at $37^{\circ} \mathrm{C}$ and the resultant turbidity was measured at $530 \mathrm{~nm}$. Controls were run.under the same conditions without the test compounds. Antimicrobial activity of each compound was tested at five different concentrations from 0.01 to $0.05 \mathrm{mg} \mathrm{ml}^{-1}$. Students $t$ test was employed to assess the statistical significance of the results.

\section{Results and discussion}

Analytical data (table 1) of the complexes indicate 1:2:1 (metal:ligand:anion) stoichiometry. All the complexes are dark brown non-hygroscopic solids. They are soluble in acetone, acetonitrile, nitrobenzene, chloroform, methanol and ethanol but insoluble in benzene, carbon tetrachloride and diethylether. The molar conductivity of the complexes in nitrobenzene $\left(25-35 \mathrm{ohm}^{-1} \mathrm{~cm}^{2} \mathrm{~mol}^{-1}\right)$ and acetonitrile $\left(121-168 \mathrm{ohm}^{-1} \mathrm{~cm}^{2} \mathrm{~mol}^{-1}\right)$ are

Table 1. Analytical and magnetic moment data of rare earth perchlorate complexes of H-NAP.

\begin{tabular}{lcccccc}
\hline Complex & $\mathrm{Ln} \%$ & $\mathrm{C} \%$ & $\mathrm{H} \%$ & $\mathrm{~N} \%$ & $\mathrm{ClO}_{4} \%$ & $\begin{array}{c}\mu_{\text {fri }} \\
(\mathrm{BM})\end{array}$ \\
\hline$\left[\mathrm{La}(\mathrm{NAP})_{2}\right] \mathrm{ClO}_{4}$ & 14.66 & 53.01 & 3.60 & 11.61 & 10.40 & - \\
& $(14.59)$ & $(52.92)$ & $(3.57)$ & $(11.76)$ & $(10.44)$ & \\
{$\left[\mathrm{Pr}\left(\mathrm{NAP}_{2}\right] \mathrm{ClO}_{4}\right.$} & 14.53 & 52.50 & 3.55 & 11.78 & 10.43 & 3.32 \\
& $(14.76)$ & $(52.81)$ & $(3.56)$ & $(11.73)$ & $(10.42)$ & \\
{$\left[\mathrm{Nd}(\mathrm{NAP})_{2}\right] \mathrm{ClO}_{4}$} & 15.10 & 52.13 & 3.50 & 11.81 & 10.50 & 3.57 \\
& $(15.06)$ & $(52.63)$ & $(3.55)$ & $(11.69)$ & $(10.38)$ & \\
{$\left[\mathrm{Sm}(\mathrm{NAP})_{2}\right] \mathrm{ClO}_{4}$} & 15.49 & 51.92 & 3.55 & 11.49 & 10.14 & 1.53 \\
& $(15.60)$ & $(52.29)$ & $(3.53)$ & $(11.62)$ & $(10.32)$ & \\
{$\left[\mathrm{Gd}(\mathrm{NAP})_{2}\right] \mathrm{ClO}_{4}$} & 16.29 & 50.95 & 3.53 & 11.65 & 10.31 & 9.79 \\
& $(16.20)$ & $(51.92)$ & $(3.50)$ & $(11.54)$ & $(10.25)$ & \\
{$\left[\mathrm{Dy}(\mathrm{NAP})_{2}\right] \mathrm{ClO}_{4}$} & 16.47 & 51.97 & 3.45 & 11.47 & 10.21 & 10.38 \\
& $(16.65)$ & $(51.64)$ & $(3.48)$ & $(11.48)$ & $(10.19)$ & \\
{$\left[\mathrm{Y}(\mathrm{NAP})_{2}\right] \mathrm{ClO}_{4}$} & 9.91 & 56.01 & 3.76 & 12.45 & 10.97 & - \\
& $(9.85)$ & $(55.85)$ & $(3.77)$ & $(12.41)$ & $(11.02)$ & \\
\hline
\end{tabular}

- Calculated values in parentheses 
in the range expected for 1:1 electrolytes (Geary 1971). Thus the complexes may be formulated as $\left[\mathrm{Ln}\left(\mathrm{NAP}_{2}\right] \mathrm{ClO}_{4}\right.$, where $\mathrm{Ln}=\mathrm{La}, \mathrm{Pr}, \mathrm{Nd}, \mathrm{Sm}, \mathrm{Gd}$, Dy and $\mathrm{Y}$.

The IR spectra (in $\mathbf{K B r}$ ) of the ligand and complexes are presented in table 2 . The medium broad band at $2900 \mathrm{~cm}^{-1}$ in $\mathrm{H}-\mathrm{NAP}$, attributable to the $\mathrm{OH}$ stretching vibration of hydrogen-bonded phenolic group, is absent in the complexes. Also the $v_{e}(\mathrm{C}-\mathrm{O})$ band of $\mathrm{H}-\mathrm{NAP}$ at $1310 \mathrm{~cm}^{-1}$ is shifted to $1325 \mathrm{~cm}^{-1}$ in the complexes. These results show that the deprotonated phenolic oxygen is coordinated (Doretti et al 1980). The strong IR band at $1660 \mathrm{~cm}^{-1}$ in $\mathrm{H}-\mathrm{NAP}$, assigned to the carbonyl stretching vibration, is shifted to $1605 \mathrm{~cm}^{-1}$ in the complexes, indicating coordination of carbonyl oxygen (Radhakrishnan et al 1984). The medium band at $1460 \mathrm{~cm}^{-1}$ in $\mathrm{H}-\mathrm{NAP}$, assigned to the $\mathrm{N}=\mathrm{N}$ stretching vibration, is intensified with a shift to $1445 \mathrm{~cm}^{-1}$ showing that the azo nitrogen is coordinated (Radhakrishnan 1985). Thus NAP ${ }^{-}$acts as a monovalent tridentate ligand in these complexes coordinating through the oxygens of the carbonyl and the phenolic groups and one of the nitrogens of the azo group, thus forming two chelate rings (one of five-membered and the second sixmembered). The IR spectra of the complexes also show a strong unsplit band at $1100 \mathrm{~cm}^{-1}$ and a medium unsplit band at $620 \mathrm{~cm}^{-1}$ assignable to the $v_{3}$ and $v_{4}$ vibrations, respectively, of ionic perchlorate, which are not present in the free ligand. Therefore, the perchlorate is not coordinated (Hathway and Underhill 1961) as confirmed by the conductance studies. Hence a coordination number of six may be assigned to the rare earth ions in these complexes.

All the absorptions due to $f-f$ transition of the $\operatorname{Pr}$ (III), Nd(III) and Sm(III) ions in the visible region are obscured in these complexes by the strong absorption of the ligand and by the charge transfer band spreading over the whole visible region.

The magnetic data (table 1) show that all the complexes, except those of La and Y, are paramagnetic as expected. The observed magnetic moment of the present complexes shows little deviation from van Vleck values (van Vleck and Frank 1929) which suggests that $4 f$ electrons, well shielded by the $5 s^{2} 5 p^{6}$ octet, play only a small role in bonding.

\subsection{Antibacterial activity}

The results of the antibacterial activity of AAP (4-aminoantipyrine), H-NAP and the complexes are given in table 3 . All the test compounds are found to show considerable antibacterial activity at a concentration of $0.05 \mathrm{mg} \mathrm{m}^{-1}$. At this dose the antimicrobial activity of AAP is highly significant. But its azo derivative H-NAP shows rather

Table 2. IR spectral data" (in $\mathrm{cm}^{-1}$ ) of rare earth complexes of H-NAP.

\begin{tabular}{|c|c|c|c|c|c|c|}
\hline Compound & $v(\mathrm{O}-\mathrm{H})$ & $v(\mathrm{C}=\mathrm{O})$ & $v(\mathrm{~N}=\mathrm{N})$ & $v_{a}(C-O)$ & $v_{3}\left(\mathrm{ClO}_{4}\right)$ & $v_{4}\left(\mathrm{ClO}_{4}\right)$ \\
\hline $\begin{array}{l}\mathrm{H}-\mathrm{NAP} \\
{\left[\mathrm{La}(\mathrm{NAP})_{2}\right] \mathrm{ClO}_{4}} \\
{\left[\mathrm{Pr}(\mathrm{NAP})_{2}\right] \mathrm{ClO}_{4}} \\
{\left[\mathrm{Nd}(\mathrm{NAP})_{2}\right] \mathrm{ClO}_{4}} \\
{\left[\mathrm{Sm}(\mathrm{NAP})_{2}\right] \mathrm{ClO}_{4}} \\
{\left[\mathrm{Gd}(\mathrm{NAP})_{2}\right] \mathrm{ClO}_{4}} \\
{\left[\mathrm{Dy}(\mathrm{NAP})_{2}\right] \mathrm{ClO}_{4}} \\
{\left[\mathrm{Y}(\mathrm{NAP})_{2}\right] \mathrm{ClO}_{4}}\end{array}$ & $\begin{array}{c}2900 \mathrm{~m}, \mathrm{br} \\
- \\
- \\
- \\
- \\
- \\
-\end{array}$ & $\begin{array}{l}1660 \text { vs } \\
1605 \text { vs } \\
1606 \text { vs } \\
1605 \text { vs } \\
1605 \text { vs } \\
1604 \text { vs } \\
1605 \text { vs } \\
1605 \text { vs }\end{array}$ & $\begin{array}{l}1460 m \\
1445 s \\
1445 s \\
1445 s \\
1445 s \\
1445 s \\
1445 s \\
1445 s\end{array}$ & $\begin{array}{l}1310 s \\
1325 s \\
1325 s \\
1325 s \\
1325 s \\
1325 s \\
1325 s \\
1325 s\end{array}$ & $\begin{array}{l}11 \bar{v} v s \\
1100 \mathrm{vs} \\
1100 \mathrm{vs} \\
1095 \mathrm{vs} \\
1100 \mathrm{vs} \\
1100 \mathrm{vs} \\
1100 \mathrm{vs}\end{array}$ & $\begin{array}{l}620 \mathrm{~m} \\
620 \mathrm{~m} \\
620 \mathrm{~m} \\
620 \mathrm{~m} \\
620 \mathrm{~m} \\
620 \mathrm{~m} \\
620 \mathrm{~m}\end{array}$ \\
\hline
\end{tabular}

' $m=$ medium; $b r=$ broad; $v s=$ very strong; $s=$ strong 
Table 3. Effect of AAP, H-NAP and rare earth perchlorate complexes of $\mathrm{H}-\mathrm{NAP}$ on the growth of bacteria at concentration of $0-05 \mathrm{mg} \mathrm{ml}$.

\begin{tabular}{|c|c|c|c|}
\hline Compound & $\begin{array}{c}\text { Mean optical } \\
\text { density at } 530 \\
\text { mm } \pm \text { standard } \\
\text { deviation }\end{array}$ & $\begin{array}{l}\text { Effect on } \\
\text { bacterial } \\
\text { growth }\end{array}$ & $\begin{array}{c}\text { Activity } \\
\text { of compound } \\
(\%)\end{array}$ \\
\hline $\begin{array}{l}\text { Control without } \\
\text { test compound }\end{array}$ & $0.422 \pm 0.008$ & & \\
\hline AAP & $0.291 \pm 0.008$ & - & $31 \cdot 1 * *$ \\
\hline H-NAP & $0.545 \pm 0.216$ & + & $10 \cdot 8^{*}$ \\
\hline$\left[\mathrm{La}(\mathrm{NAP})_{2}\right] \mathrm{ClO}_{4}$ & $0.327 \pm 0.038$ & - & $22 \cdot 6^{* *}$ \\
\hline$\left[\operatorname{Pr}(\mathrm{NAP})_{2}\right\rfloor \mathrm{ClO}_{4}$ & $0.324 \pm 0.026$ & - & $23 \cdot 6^{* *}$ \\
\hline$\left[\mathrm{Nd}(\mathrm{NAP})_{2}\right] \mathrm{ClO}_{4}$ & $0.367 \pm 0.042$ & - & $13 \cdot 9 * *$ \\
\hline$\left[\mathrm{Sm}(\mathrm{NAP})_{2}\right] \mathrm{ClO}_{4}$ & $0-387 \pm 0-045$ & - & $8 \cdot 3^{*}$ \\
\hline$\left[\mathrm{Gd}(\mathrm{NAP})_{2}\right] \mathrm{ClO}_{4}$ & $0-320 \pm 0-028$ & - & $24 \cdot 2 * *$ \\
\hline$\left[\mathrm{Dy}(\mathrm{NAP})_{2}\right] \mathrm{ClO}_{2}$ & $0-315 \pm 0-040$ & - & $25 \cdot 4^{*}$ \\
\hline$\left[\mathrm{Y}(\mathrm{NAP})_{2}\right] \mathrm{ClO}_{4}$ & $0.308 \pm 0-024$ & - & $27 \cdot 1 * *$ \\
\hline
\end{tabular}

* Significant at 005 level

**Significant at 0 -01 level

a nutrient effect on the bacterial growth. This may be due to the loss of two hydrogen atoms on the amino group of AAP (Fox and Gibas 1955). Among the complexes the anti-staphylococcal activity with respect to the rare earth ion shows the order $\mathrm{Y}>\mathrm{Dy}>\mathrm{Gd}>\mathrm{Pr}>\mathrm{La}>\mathrm{Nd}>\mathrm{Sm}$. However, the antibacterial activity of the complexes is less than that of AAP but greater than that of H-NAP. This is due to the inhibitory involvement of the metal ion, perchlorate ion, complex ion or the complex as a whole in the growth of S. aureus (Fox and Gibas 1955).

\section{Acknowledgement}

The authors thank the State Committee on Science, Technology and Environment, Government of Kerala, Thiruvananthapuram for financial aid.

\section{Refereaces}

Alaudeen M and Radhakrishnan P K 1990 Synth. React. Inorg. Met.-Org. Chem. 20(6) 678 Doretti L, Sitran S, Madalosso F, Bandoli G and Paolucci G 1980 J. Inorg. Nucl. Chem. 421060 Fox H H and Gibas J T 1955 J. Org. Chem. 2060 Geary W J 1971 Coord. Chem. Rev. 781

Hathaway B J and Underhill A E $1961 \mathrm{~J}$. Chem. Soc. 3091

Hogale H B et al 1989 J. Indian Chem. Soc. 66361

Kurz K, Kober G and Berl M 1958 Anal. Chem. 301983

Nair M R G, Kurien M J and Prabhakaran C P 1981 Talanta 48395

Radhakrishnan P K 1985 J. Less Common Met. 1075

Radhakrishnan P K, Indrasenan P and Nair C G R 1984 Polyhedron 367

Raymond Br J and Mahan Mc 1944 J. Biol. Chem. 153247

Schmidt W H and Mayer A J 1944 J. Bacteriol. 47199

Sharpe W E 1955 J. Appl. Bacteriol. 18274

van Vleck J H and Frank N 1929 Phys. Rev. 341499 